\title{
Erratum to: Genome sequencing, annotation and comparative genomic analysis of Shigella dysenteriae strain SD1D
}

Gurwinder Kaur ${ }^{1 \dagger}$, Sathyaseelan Sathyabama ${ }^{2 \dagger}$, Amit Arora', Sheenam Verma ${ }^{2}$, Nida Mubin², Javed N. Agrewala ${ }^{2^{*}}$ and Shanmugam Mayilraj ${ }^{*}$

\section{Erratum to: Gut Pathog (2014) 6:28 DOI 10.1186/1757-4749-6-28}

Following publication of the article in Gut Pathogens [1], it was brought to our attention that the isolation date mentioned in the Methods section is incorrect and should read October 9, 2012 instead of March 19, 2013. The full sentence should read:

"Shigella dysenteriae strain SD1D was isolated from stool sample of a healthy individual on Oct 9, 2012, using tryptic soya agar (TSA, HiMedia, India)."

The online version of the original article can be found under doi:10.1186/1757-4749-6-28.

Received: 11 July 2016 Accepted: 28 July 2016

Published online: 10 August 2016

\section{Reference}

1. Kaur G, Sathyabama S, Arora A, Verma S, Mubin N, Agrewala JN, Mayilraj S.

Genome sequencing, annotation and comparative genomic analysis of

Shigella dysenteriae strain SD1D. Gut Pathog. 2014;6:28.

\footnotetext{
*Correspondence: javed@imtech.res.in; mayil@imtech.res.in

${ }^{\dagger}$ Gurwinder Kaur and Sathyaseelan Sathyabama contributed equally to

this work

${ }^{1}$ Microbial Type Culture Collection and Gene Bank, CSIR-Institute

of Microbial Technology, Sector 39A, Chandigarh 160036, India

${ }^{2}$ Immunology Laboratory, CSIR-Institute of Microbial Technology, Sector

39A, Chandigarh 160036, India
} 